日消外会誌 $11(8): 616 \sim 620,1978$ 年

特 集 $3^{*}$

食道静脈瘤に対する直達手術の比較検討

\begin{tabular}{|c|c|c|c|c|c|}
\hline \multicolumn{6}{|c|}{ 東京大学第 2 外科 } \\
\hline 二川 & 俊二: & 杉浦 & 光雄: & 島 & 文夫 \\
\hline 別府 & 倫兄 & 上笹 & 功 & 深沢 & 正樹 \\
\hline 三條 & 健舀 & 和用 & 達雄 & & \\
\hline
\end{tabular}

\title{
NONSHUNTING PROCEDURES IN THE TREATMENT OF ESOPHAGEAL VARICES
}

\author{
Shunji FUTAGaWA, Mitsuo SUgIURA, Fumio SHIMA, \\ Tomoe BEPPU, Isao KAMIZASA, Masaki FUKAZAWA, \\ Kensho SANJO and Tatsuo WADA
}

The 2nd Department of Surgery, Faculty of Medicine, University of Tokyo

索引用語: 門脈圧穴進症, 食道静脈瘤, 直達手術, 食道離断術, 中下部食道・胃噴門部血行遮断

はじめに

食道静脈瘤の外科治療としては, 門脈王の減圧を目的 とする血管吻合術と静脈瘤に直接侵意を加兄る直達手術 とに大別される。教室でる昭和39年までは各種の血管吻 合手術が試みられたが，肝性脳症の発生，吻合口の閉塞 による再吐血などの術後合併症のため ${ }^{1) ~}$ ，昭和39年以 後は直達手術を標準術式として行い, 主として開胸によ る食道離断術を採用してきた．さらに昭和 42 年からは開 胸・開腹による中下部食道・胃噴門部の広沉な血行遮断 を伴う食道離断術いわゆる東大第 2 外科法を行ってき $た^{5) 6)}$.

今回は現在の標準術式である食道離断術（東大第 2 外 科法）の成續を中心に，その他の直達手術の成績との比 較検討を行った。

$$
\text { 対 象 }
$$

対象症例は，教室で直達手術を採用した昭和39年以 来の直達手術施行症例で, 総症例数は371例である（表 1). その内訳は Walker ${ }^{7}$ による単純食道離断術例26 例，それに左胃静脈切除術を付加したもの14例，経腹的 な下部食道離断に下部食道・胃噴門部血行遮断を加えた いわゆる経腹的食道離断例 6 例, Hassab ${ }^{8)}$ ') による食道

*第11回日䏴外総会シンポ II 食道静脈瘤の直達手衍とその適応
表 1 㨁達手術症例 S53. 2

\begin{tabular}{|c|c|}
\hline 術 & 例数 \\
\hline 経胸的単純食道離断 (Walker) & 26 \\
\hline 経购的単純食道離断十左閴静脈切除 & 14 \\
\hline 経胸的食道離断(東大二外法) & 311 \\
\hline 経脢的食道離断 & 6 \\
\hline 下部食道・胃喷門部血行遮断(Hassab) & 14 \\
\hline 計 & 371 \\
\hline
\end{tabular}

離断は行わずに下部食道・胃噴門部の血行遮断のみを行 ったもの14例, 開胸・開腹による食道離断（東大第 2 外 科法) 例311例となっている。

\section{成 綂}

手術直接成績を検討すると, 手術死は単純食道離断術 に1 例, 3.8\%, 食道離断術例に15例 $4.8 \%$, みられたに すぎずその他の術式では 手術症例数が少ないことも1 因と考兄られるが，手術死はみられていない(表 2)。 単純食道離断術例での手術死は胿障害高度の繁急例で, 食道離断例でも緊急例が手術死の約半数を占めて扣り, 緊急例の手術成績がが最も悪くなっている. 手術死因を みてみると, 術式のいかんを問わず, 肝不全死, 肝癌死 など原疾患が，その死因のほとんどを占め，手術手技が 関与していると思われるのは膿胸死の 2 例のみであり， その意味からは直達手術はいずれの術式でも比較的安 
表 2 手術成績 S53，2

\begin{tabular}{|c|c|c|c|c|c|}
\hline \multirow{2}{*}{ 衙 式 } & \multirow{2}{*}{ 例 } & \multirow{2}{*}{ 手術死 } & \multirow{2}{*}{ 㗨急例 } & \multicolumn{2}{|c|}{ 瑀急例手衡死 } \\
\hline & & & & 例数 & $\%$ \\
\hline $\begin{array}{l}\text { 単純食道離断 } \\
\text { (Walker) }\end{array}$ & 26 & 1 & 4 & 1 & 25 \\
\hline 十左霄静眽切除 & 14 & 0 & 0 & 0 & 0 \\
\hline 站道離断(東大2外法) & 311 & 15 & 57 & 8 & 14 \\
\hline 経腹的食道離断 & 6 & 0 & 0 & 0 & 0 \\
\hline 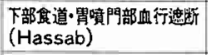 & 14 & 0 & 0 & 0 & 0 \\
\hline 計 & 371 & 16 & $6 !$ & 9 & 15 \\
\hline
\end{tabular}

表 3 直達手術の手術死因 S 53. 2

\begin{tabular}{|c|c|c|c|c|c|c|c|}
\hline \multirow{2}{*}{ 䚘式 } & \multirow{2}{*}{$\begin{array}{l}\text { 例 } \\
\text { 数 } \\
\end{array}$} & \multirow{2}{*}{\begin{tabular}{|l} 
手 \\
䚘 \\
死
\end{tabular}} & \multicolumn{5}{|c|}{ 手術死因 } \\
\hline & & & 肝不全 & 肝癌 & 吐血 & 脳腹 & 他 \\
\hline 食亨聚急手術 & 57 & 8 & 4 & 2 & 0 & 0 & 2 \\
\hline 道尖待期手術 & 180 & 3 & 1 & 0 & 0 & 1 & 1 \\
\hline 離外予防的手術 & 74 & 4 & 3 & 0 & 0 & 1 & 0 \\
\hline 断法 $\quad$ 計 & 311 & 5 & 8 & 2 & 0 & 2 & 3 \\
\hline $\begin{array}{c}\text { 単 純 食 道 離 断 } \\
\text { (Walker) }\end{array}$ & 26 & 1 & 1 & 0 & 0 & 0 & 0 \\
\hline 棓 & 337 & 16 & 9 & 2 & 0 & 2 & 3 \\
\hline
\end{tabular}

表 4 直達手術の後期死因 S 53. 2

\begin{tabular}{|c|c|c|c|c|c|c|c|c|}
\hline \multirow{2}{*}{ 畐 } & \multirow{2}{*}{$\begin{array}{l}\text { 例 } \\
\text { 数 }\end{array}$} & \multirow{2}{*}{$\begin{array}{l}\text { 秉 } \\
\text { 禁 } \\
\text { 死 }\end{array}$} & \multirow{2}{*}{ 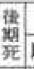 } & \multicolumn{4}{|c|}{ 後 期 死 因 } & \multirow{2}{*}{$\begin{array}{l}\text { 告 } \\
\text { 丵\% }\end{array}$} \\
\hline & & & & 肝不全 & 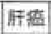 & 昍血\% & 㭉他 & \\
\hline $\begin{array}{l}\text { 单純英道敖断 } \\
\text { (W alker) }\end{array}$ & 26 & 1 & 6 & 2 & 0 & $\begin{array}{ll}4 & \\
& 67 \\
\end{array}$ & 0 & 73 \\
\hline 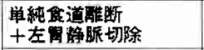 & 14 & 0 & 6 & 2 & 1 & 33 & 1 & 57 \\
\hline $\begin{array}{l}\text { 食 道 離 断 } \\
\text { (東大外) }\end{array}$ & 311 & 15 & 40 & 20 & 12 & 2 & 6 & 82 \\
\hline 経腹的食道離断 & 6 & 0 & 1 & 0 & 0 & $\begin{array}{ll}1 & \\
& 100\end{array}$ & 0 & 83 \\
\hline 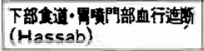 & 14 & 0 & 3 & 0 & 1 & $\begin{array}{ll}1 & \\
& 33\end{array}$ & 1 & 79 \\
\hline
\end{tabular}

全な術式とい完る（表 3 ）. 次飞，後期死因をみてみる と，東大法以外では，いずれの術式でも吐血死が高率に みられているが，東大法では手術死因と同しく，肝不全 死，肝癌死など原疾患に関係がある死因が大部分を占め ている（表 4). 東大法のみでの 生存率をみてるると, 術式のいかんを問わず原疾患の重症度によってその生 存率が左右されるようで（表 5 ），䀒機能の最る不良な Child 分類のC群が最も悪く，いずれも50\%台の生存率 になっている，東大法では出血再発死が少ないため，そ の成續は，他の直達術式に比してょり原疾患の障害程度 を反影しているょうである。

次に，手術効果として，各種術式の静脈瘤への効果を みると，静脈瘤消失率は東大法が97\%と良好な満足すべ き結果をみている以外は，いずれの術式でも50〜60\% 前 後の静脈瘤消失率で不満足な結果となっている(表 6). ここでいら不変例とは静脈瘤再発例で再出血例を不変例
表 5 Child の分類比上る手術成績（東大 2 外法）

（予防的手術） 553.2

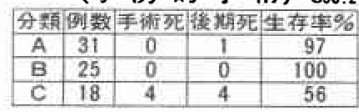

(待 期 手術)

\begin{tabular}{|c|c|c|c|c|}
\hline 적 & 晒数 & 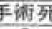 & 线期? & 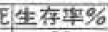 \\
\hline A & 91 & 0 & 6 & 93 \\
\hline B & 66 & 1 & 11 & \\
\hline C & 23 & 2 & 8 & 57 \\
\hline
\end{tabular}

（婜急手術）

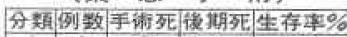

\begin{tabular}{|c|c|c|c|c|}
\hline A & 8 & 0 & 1 & 88 \\
\hline B & 21 & 0 & 4 & 81 \\
\hline C & 28 & 8 & 5 & 54 \\
\hline
\end{tabular}

表 6 静脈溜への効果 $\mathrm{S} 53.2$

\begin{tabular}{|c|c|c|c|c|c|}
\hline \multirow{2}{*}{ 街 } & \multirow{2}{*}{$\begin{array}{l}\text { 例 } \\
\text { 数 }\end{array}$} & \multirow{2}{*}{ 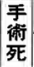 } & \multicolumn{3}{|c|}{ 静 挢 瘤 } \\
\hline & & & 消失 \% & 改善 & 不变 \\
\hline $\begin{array}{l}\text { 単純食道離断 } \\
\text { (Walker) }\end{array}$ & 26 & 1 & $\begin{array}{ll}12 & \\
48\end{array}$ & 8 & 5 \\
\hline $\begin{array}{l}\text { 単純食道離断 } \\
\text { 十左成静㟲切除 }\end{array}$ & 14 & 0 & ${ }^{9} 64$ & 3 & 2 \\
\hline $\begin{array}{l}\text { 食 道㰚 断 } \\
\text { (東大2外法) }\end{array}$ & 311 & 15 & $\begin{array}{ll}287 & 97 \\
\end{array}$ & 5 & 4 \\
\hline 経腹的食道離断 & 6 & 0 & ${ }^{3}$ & 1 & 2 \\
\hline 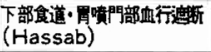 & 14 & 0 & ${ }^{7}{ }_{50}$ & 7 & 0 \\
\hline
\end{tabular}

表 7 経腹的食道離断症例 S 53.2

\begin{tabular}{|c|c|c|c|c|c|}
\hline \multirow{2}{*}{ 症 例 } & \multirow{2}{*}{ 手術 } & \multirow{2}{*}{ 䀒粗较 } & \multicolumn{2}{|c|}{ 血行遮断䇛囲 } & \multirow{2}{*}{ 静眽疾 } \\
\hline & & & 真通 $\mathrm{cm}$ & 唃"7"m & \\
\hline 1. 46 才 & 待期 & L. C & 12 & 5 & 消 失 \\
\hline $247 \neq 3$ & 持期 & L. C & 13 & 5 & 軽 快 \\
\hline 3. $64 \succsim+q$ & 待期 & L. $C$ & 12 & 7 & $\begin{array}{c}\text { 否要 } \\
\text { (再叶血) }\end{array}$ \\
\hline 4. $45 才 \delta$ & 予防 & ᄂ. C & 11 & 6 & 消 失 \\
\hline 5. 59才令 & 待期 & L. C & (this 18 & 6 & $\begin{array}{c}\text { 不 } \\
\text { (銐吐血) }\end{array}$ \\
\hline 5. 43 & 予防 & L. F & 13 & 6 & 消 \\
\hline
\end{tabular}

\section{として分類した。}

経腹的食道離断術は 6 例経験したが，それぞれの血行 遮断の範囲は表 7 亿示すごとく下部食道で，最短例で $11 \mathrm{~cm}$ ，最長例は症例 5 の横隔膜を切開して出きうる限 り口側まで血行遮断を行った症例で $18 \mathrm{~cm}$ 行った。この 症例 5 は広汎な血行遮断にもかかわらず術後 1 カ月に再 発食道静脈瘤からの再出血をきたし，緊急内視鏡でもこ のことが確認された．本術式での予防的手術を除いた出 血例のみでの手術効果をみてみると 4 例中 2 例と，その 半数に再出血をみて括り，経腹的食道離断術では期待し た手術効果が十分得られないと思われる。

次に，下部食道・胃噴門部血行遮断術式の静脈瘤への 効果をみてみると，総症例14例中静脈瘤が胃にのみ限局 
している症例では全例, 静脈瘤消失をみて100\%の効果 が認められるが，静脈瘤が食道にも存在する癖例では， 手術効果も不十分で，30\%の消失率をみたにすぎなかっ た（表８）。なお，本術式施行症例は静脈溜置限局症例 の 2 例のみが出血症例でその他は全例末出血例であるの で, 静脈瘤への効果判定は, 内視鏡観察掞よびX線観察 による性状，形状によって行った。

表 8 Hassab 術式の静脈瘤への効果 S 53. 2

\begin{tabular}{|c|c|c|c|c|}
\hline \multirow{2}{*}{ 術前静眽癌 } & \multirow{2}{*}{$\begin{array}{l}\text { 例 } \\
\text { 数 }\end{array}$} & \multicolumn{3}{|c|}{ 術後静脈㿔 } \\
\hline & & 消失 \% & 改善 & 不変 \\
\hline 胃に限局 & 4 & $4100 \%$ & 0 & 0 \\
\hline 固および食道 & 10 & $3 \quad 30 \%$ & 3 & 4 \\
\hline 計 & 14 & $7 \quad 50 \%$ & 3 & 4 \\
\hline
\end{tabular}

表 9 術後出血の原因 S 53.2

\begin{tabular}{|c|c|c|c|c|c|c|c|c|}
\hline \multirow{2}{*}{ 衏 } & \multirow{2}{*}{ 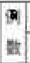 } & \multicolumn{2}{|c|}{ 出血 } & \multicolumn{5}{|c|}{ 原 } \\
\hline & & 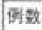 & 96 & 显㾂 \% & 而炎 & 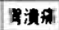 & 用舴 & 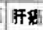 \\
\hline 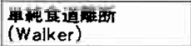 & 26 & 7 & 28 & 71 & 2 & 0 & 0 & 0 \\
\hline 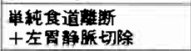 & 14 & 4 & 29 & 50 & 0 & 2 & 0 & 0 \\
\hline $\begin{array}{l}\text { 食道離断 } \\
\text { (東大外法) }\end{array}$ & 31 & 20 & 67) & 20 & 11 & 1 & 1 & 3 \\
\hline 栍㜔的食道離断 & 6 & 2 & 33 & 100 & 0 & 0 & 0 & 0 \\
\hline $\begin{array}{l}\text { 下部食道・胃䜖門部血行遮斯 } \\
\text { Hassab) }\end{array}$ & 14 & 1 & 7.1 & 1000 & 0 & 0 & 0 & 0 \\
\hline
\end{tabular}

直達手術術後の再出血の原因を検討してみると，東大 法以外の術式では, 静脈瘤再発による再出血がその主要 原因となっているのに反して, 東大法では出血性胃炎が 主要原因となっている（表9）。しかし 単純食道離断術 例での胃炎発生率 2 例, $8 \%$ に対し, 東大法では11例, $3.7 \%$ であり, 胃炎発生率が東大法で特徽的に 高いわけ ではない，その他の術式では，症例数が少ないためか， 胃炎の発生はみられていない，術後合併症としては直達 術式に特徴的なのは縫合不全と狭窄である（表10）。縫

表10 合併症 S 53.2

\begin{tabular}{|c|c|c|c|c|c|c|c|}
\hline 微 & $\begin{array}{l}\text { 烧不 } \\
\text { 合全 }\end{array}$ & $\begin{array}{l}\text { 狭 } \\
\text { 䇤 }\end{array}$ & $\begin{array}{l}\text { 栞 } \\
\text { 全 }\end{array}$ & $\begin{array}{l}\text { 督 } \\
\text { 全 }\end{array}$ & $\begin{array}{l}\text { 学 } \\
\text { 出 } \\
\text { 恶 }\end{array}$ & $\begin{array}{l}\text { 中 } \\
\text { 䈣 } \\
\end{array}$ & at \\
\hline 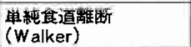 & 0 & 1 & 0 & 0 & 0 & 0 & 1 \\
\hline 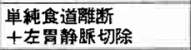 & 0 & 0 & 0 & 0 & 0 & 0 & 0 \\
\hline $\begin{array}{l}\text { 食 道 離 断 } \\
\text { (東大二外法) }\end{array}$ & $\begin{array}{l}19 \\
(2)\end{array}$ & 9 & $\begin{array}{c}6 \\
(6)\end{array}$ & 1 & 1 & 1 & 37 \\
\hline 経腹的食道離紤 & 0 & 0 & 0 & 0 & 0 & 0 & 0 \\
\hline 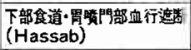 & 0 & 1 & 0 & 0 & 0 & 0 & 1 \\
\hline
\end{tabular}

合不全は当然なことながら，血行遮断を徹底して行う東 大法のみに19例みられている。しかし膿胸を併発して死 亡した症例は 2 例のみで, 残り17例全例，経鼻管栄養で 治療している. 狭窄も東大法で 9 例，3\%の発生をみて いるが，いずれもブジールング，内視鏡による切開など で治癒軽快している．食道離断を行っていない Hassab の術式症例においても1例みられていることは，注目す べきことと思われる。

\section{考察}

門脈圧充進症による食道静脈瘤の外科治療としては, 現在，主として直達手術と選択的門脈圧減圧法 ${ }^{(0)}$-15) 行われているが，選択的血管吻合術は脳症の発生は防げ ても，吻合術の宿命から長期間の観察では吻合口の閉塞 が問題となると思われ，本邦では直達手術が主流をなし ているのが現況である．とくに食道離断術は数多くの施 設で試みられ好成績をあげている。

教室でも食道静脈瘤の外科治療として, 種々の直達手 術を経験したが，手術死亡，すなわち手術值接成績に関 してはいずれの直達手術も安全な術式といえる。しかし 手術の効果すなわち静脈瘤への効果を考慮すれば，中下 部食道・胃噴門部の広汎な血行遮断を伴う開胸開腹によ る食道離断術 (東大第 2 外科法) が最も優れた術式と考 えられる、静脈瘤への十分な効果を得るためには広沈な 血行遮断が不可欠であり, 開腹のみでの血行遮断では不 十分である.このことは術後の血行遮断範井検討でも証 明されている．写真1は直達手術術後のレ線写真であ る. 矢印のクリップはそれぞれ血行遮断範囲の上端を示 しているが，左は経腹的食道離断術症例，中は同術式症

写真 1

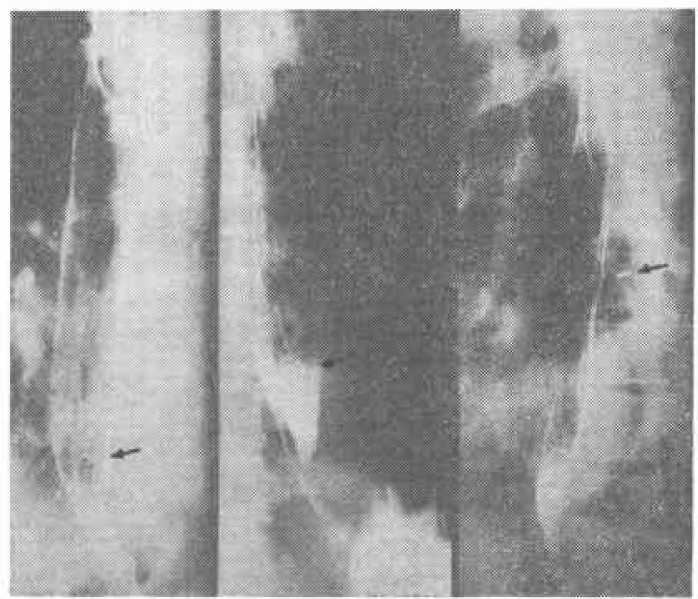


例 5 で横隔膜切開によりできらる限り口側まで血行遮断 した症例でする。，それぞれの術中食道血行选断範团は左 が $12 \mathrm{~cm}$, 中が $18 \mathrm{~cm}$, 右は左下肺静脈上縁までである. 中の症例 5 は既述したごとく術後 1 カ月に静脈瘤からの 再吐血をみている.祭腹操作のみと, 開胸操作を加えた のとでは血行㴧断範囲に格段の差がみられ開腹操作のみ では折行遮断は不十分なようである。一般に腹部操作の みでは權隔膜食道勒带の上行葉を越えて口側までの血行 遮断は不可能なようで，このことが経腹的食道離断症例 での不满足な結果の主要原因と考党られる。このことは 東大第 2 外科法以外心術式すべてにあてはまることであ る、事实，術中しばしば上行葉よりもはるかに口側で食 道静脈晑への巨大交通枝がみられるが，これら交通枝の 切離が他術式では不可能と考えられる。

経腹的食道離断術に比し, 東大第 2 外科法は静脈瘤一 の效果が良好な他に，重症例にはまず開胸操作のみを行 い患者の回復を待って経腹操作が行えるので，すなわち 二期分割手術として行えるので，手術侵襲が少なく，よ り安全な術式といえる．また手術手技的にも私どもの経 験からは，開腹のみで行う食道離断に比し，開胸による 食道離断は直視下に十分な広手術野が得られるので食道 をより愛護的に確実から容易に離断綘合操作が行えるな どの利伃があげられる。したがって食道離断に関しては 閶胸開腹による術式が最も優れた術式と考觉られ，本術 式は予防的にも待期的, 緊急的にも勧められる術式であ る.

食道陮断術（東大第 2 外科法）の成功の要点は, 十分 な血行遮断を口側は左下肺静脈上縁より肛側は小弯側で 左胃動脈の胃角に向ら分枝の最終分枝を2 本残すまで行 うことでめり，Poor-risk 症例で二期分割手術とした場 吕, 血行遮断を二期手術操作時に一期手術操作時の血行 滥断範用を越えてさらに $1 \mathrm{~cm}$ 程重複して行い静脈瘤へ の流入血管を残さないよう血行遮断を確実に行うこと であり，また特殊な食道離断用鉗子，無賃針の使用など により食道離断部をできうる限り愛護的に取り扱うこと であろう、食道離断の際, 筋層を完全離断とするか半周 離断とするかは, 広汎な血行遮断を行っていること, 释 合不全の危険性の堌大, 半周のみ離断の現行術式の成績 などより考觉て, 筋層は半周離断で十分と考学ている.

静脈瘤が食道になく胃にのみ限局されている症例に対 しては開腹のみによる下部食道・胃噴門部血行遮断術， いわゆる Hassab の術式 ${ }^{89)}$ は効果的であり, 勧められ る術式と考えている。
直達手術として, 一部食道噴門部切除術, 喷門部切除

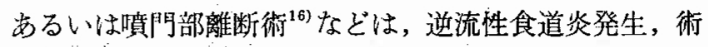
後狭窘, 血行遮断範囲の不十分性などの可能性より考兄 て, 十分満足のいく手術結果を得るには今後さらに検討 の要があると考えている.

\section{おわりに}

教室で経験した食道静脈溜に対する各種直達手術につ いて比較検討 $し$, 手術成績, 遠隔成績, 手術手技, 合併 症などの概略について述べた。現在の標準術式である東 大第 2 外科法による食道離断術は最も满足すべき手術結 果をみており，手術造応が極めて広いと考えている.

本論文の要旨は第11回日本消化器外科学会総会シンポ ジウムにおいて発表した。

\section{文献}

1) Orloff, M.J. et al.: Portacaval shunt as emergency procedure in unselected patients with alcoholic cirrhosis. S.G.O., 141: 5968, 1975.

2) Drapanas, T.: Interposition mesocaval shunt for treatment of portal hypertension. Ann. Surg., 176: 435-448, 1972.

3) Drapanas, T. et al.: Hemodynamics of the interposition mesocaval shunt. Ann. Surg., 181: $523-533,1975$.

4) 二川俊二: Eck 瘦症状群の研究. 日本外科学会 雑誌, $73: 310-324,1972$.

5) 杉浦光雄ほか：門脈圧六進症の外科治療一とく に東大第 2 外科法について一. 日本医事新報, $2410: 7-10,1970$.

6) Sugiura, M. et al.: A new technique for treating esophageal varices. J. Thorac. Cardiovasc. Surg., 66: 677-685, 1973.

7) Walker, R.M.: Transection operations for portal hypertension. Thorax, 15: 218-224, 1960.

8) Hassab, M.A.: Gastroesophageal decongestion and splenectomy: Preliminary report. J. Int. Coll. Surg., 41: 232-248, 1964.

9) Hassab, M.A.: Gastroesophageal decongestion and splenectomy in the treatment of esophageal varices in bilharzial cirrhosis. Surg., 61: $169-176,1967$.

10) Warren, W.D. et al.: Selective trans-splenic decompression of gastroesophageal varices by distal splenorenal shunt. Ann. Surg., 166: 437-455, 1967.

11) Huston, D.G. et al.: The fate of esophageal varices following selective distal splenorenal shunt. Ann. Surg., 183: 496-501, 1976.

12) Vang, J. et al.: Results of a modified distal 
spleno-renal shunt for portal hypertension. Ann. Surg., 185: 224-228, 1977.

13)、井口漈はか：本邦における胿硬変性食道静眽 留出血患者の実態とその対策. 福岡医学雑誌, $59: 1-34,1968$.

14) Mosimann, $R$. et al.: Efficacy and risks of the distal splenorenal shunt in the treatment of bleeding esophageal varices. Am. J. Surg., 133: $163-168,1977$.
15) Vang, J. et al.: Results of a modified distal splenorenal shunt for portal hypertension. Ann. Surg., 185: 224-228, 1977.

16) Yamamoto, S. et al.: The late results of terminal esophagoproximal gastrectomy with extensive devascularization and splenectomy for bleeding esophageal varices in cirrhosis. Surg., 80: 106-114, 1976. 